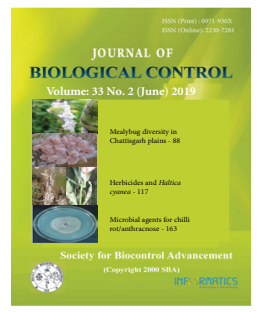

Research Article

\title{
Molecular characterisation of tomato leaf miner Tuta absoluta populations obtained from different geographical locations of India
}

\author{
ASHOK B. HADAPAD ${ }^{1}$ and RAMESH S. HIRE ${ }^{1,2^{*}}$ \\ ${ }^{1}$ Nuclear Agriculture \& Biotechnology Division, Bhabha Atomic Research Centre, Trombay, Mumbai - 400085, Maharashtra, \\ India \\ ${ }^{2}$ Homi Bhabha National Institute, Training School Complex, Anushaktinagar, Mumbai - 400094, Maharashtra, India \\ ${ }^{*}$ Corresponding authorE-mail: rshire@barc.gov.in
}

\begin{abstract}
The tomato leaf miner, Tuta absoluta (Meyrick) is one of the major invasive insect pests on solanaceous crops. T. absoluta distribution is observed in European, North African Mediterranean basin and Asian countries. The tomato leaf miner is spreading fast and affecting tomato production in both closed and open-field conditions. This insect pest has recently reported in various tomato growing regions of India and causing significant loss of production. In the present study, occurrence of a tomato leaf miner was studied by undertaking an extensive survey in tomato growing regions of India during September 2017 to May 2018. The infestation of T. absoluta was recorded in Maharashtra, Karnataka, Telangana, Tamil Nadu, Haryana and Himachal Pradesh. Severe incidence of T. absoluta infestation was recorded in Maharashtra (Nashik district) and Telangana (Mahabubnagar district) followed by Karnataka (Kalaburgi and Raichur districts). The moths collected during the survey were characterized using mitochondrial cytochrome c oxidase subunit I (COI) gene analysis. The T. absoluta samples showed maximum genetic similarity with KU565720 Kenya, KT452897 Oman, KY212128 South Africa, KY619687 India, KP814057 India and KJ657679 Florida. Nine T. absoluta populations were grouped under a single clade revealing no genetic variation within populations and showed high genetic homogeneity thereby the ideal candidate for sterile insect technique application. Further studies are required on population dynamics, host range, local and area-wide biological control management strategies for the effective management of T. absoluta.
\end{abstract}

KEY WORDS: MtCOI, phylogenetic analysis, SIT, Tuta absoluta

(Article chronicle: Received: 16-11-2018; Revised: 10-02-2019; Accepted: 23-03-2019)

\section{INTRODUCTION}

Tomato leaf miner, Tuta absoluta (Meyrick, 1917) (Lepidoptera: Gelechiidae) is a major and invasive pest of tomato and other Solanaceous crops in the world (Zappala et al., 2013; Tonnang et al., 2015; Biondi et al., 2018). While, Solanaceae plants are the main host plants for T. absoluta, tomato (Solanum lycopersicum L.), eggplant (Solanum melongena L.), potato (Solanum tuberosum L.), pepper (Capsicum annum L.), tobacco (Nicotiana tabacum L.) are the major hosts apart from other solanaceous weeds (Desneux et al., 2010; Bawin et al., 2016; Abbes et al., 2016; Biondi et al., 2018). Generally, T. absoluta attacks all developmental stages of plants, exhibits high reproduction potential and dispersal ability. Female adult lay eggs on leaves and early fruits, the neonate larvae enter the mesophyll, which forms galleries, thereby making the plant prone to secondary infection by pathogens. The larvae can also enter the stem through buds, flowers, and causes severe damages resulting complete loss of the plant. Eventually, all these events lead to reducing both quality and yield of tomato (Desneux et al., 2010; Ballal et al., 2016). Tomato leaf miner was first reported in 1914 in Peru, and currently this insect is a common pest in South America (Jham et al., 2001). During 2006, T. absoluta was reported from Spain and then onwards it rapidly invaded across the Mediterranean coastal tomato-producing areas (Desneux et al., 2010; Desneux et al., 2011). Later, it invaded Europe, Africa and Asia, where it is causing significant damage to tomato crop (Desneux et al., 2011; Ballal et al., 2016; Biondi et al., 2018).

In India, T. absoluta was first reported during 2014-15 in and around Bengaluru in Karnataka (Sridhar et al., 2014) and Pune in Maharashtra (Shashank et al., 2015). Subsequently, it has been reported from several states of India causing up to $90.0-100.0 \%$ tomato fruit damage (Kalleshwaraswamy et al., 2015; Kumari et al., 2015; Ballal et al., 2016; Swathi et al., 2017; Rasheed et al., 2017; Sidhu et al., 2017; Balaji et al., 2018). Thus, it is considered as a key pest of closed as well as open-field tomato cultivation which threatens tomato growers and allied industries. 
Currently, selected insecticides, pheromone traps, biorational insecticides, egg parasitoids and resistant varieties of tomato are being used for suppression of Tuta population (Zappala et al., 2013; Ballal et al., 2016; Biondi et al., 2018), but mainly the control is based on the broad spectrum insecticides. However, insecticide-resistance problems have already been reported from several parts of the world (Siqueira et al., 2000; Lietti et al., 2005; Campos et al., 2015). The tomato leaf miner is known to have high reproductive potential, greater adaptability, and invasion capacity, hence considered for a world-wide pest management programme to curtail economic losses. The Sterile Insect Technique (SIT) is an environmentally friendly, sustainable and speciesspecific method of pest control based on mass rearing of the target pest, sterilization and releasing of sterile males (Dyck et al., 2005). The sterile males will mate with wild females of the target pest population and are unable to produce viable offspring (Dyck et al., 2005). This method has been successfully employed against various lepidopteran insect pests, including Cydia pomonella (Linnaeus), Pectinophora gossypiella (Saunders) (Tan, 2000; Bloem et al., 2005). The effects of gamma radiation on several moths have also been investigated including T. absoluta (Cagnotti et al., 2012; Kuyulu and Genc, 2016).

The success of pest management relies on the proper identification of target insect pests, which are generally identified based on morphological features (Karthika et al., 2016). Molecular characterization and DNA barcoding is a standard taxonomic method that uses a short genetic marker in an insect DNA to identify a species (Jalali et al., 2015). Partial DNA sequences of the mitochondrial gene such as cytochrome c oxidase subunit I (COI), Internal Transcribed Spacer (ITS) regions of rDNA and other molecular markers have been used to assess genetic diversity of $T$. absoluta populations (Suinaga et al., 2004; Cifuentes et al., 2011; Bettaïbi et al., 2012; 2016; Shashank et al., 2018). The study of genetic variability of invasive T. absoluta is essential to develop an efficient Integrated Pest Management (IPM) programs (Bettaïbi et al., 2012). In this study, we have made an extensive survey to collect the wild population of T. absoluta from different locations of India and identify the Tuta samples using COI gene analysis.

\section{MATERIALS AND METHODS}

\section{Field survey and collection of tomato leaf miner samples and storage}

The tomato leaf miner infestation on tomato crop field was identified with the help of National Research Institutes and Agricultural Universities. We used tomato leaf miner pheromone lures from Pest Control (India) Pvt. Ltd. to survey and collect Tuta absoluta samples. The samples were collected from various locations of different states during September 2017-May 2018 (Table 1). For each location, 4-5 tomato crop fields were identified and traps were installed. The funnel traps were placed $40 \mathrm{~cm}$ above the ground and a spacing of $20 \mathrm{~m}$ was maintained between the traps. Individual moths collected from pheromone traps were kept in separate vials with $800 \mu \mathrm{l}$ of absolute ethanol and kept at $-25^{\circ} \mathrm{C}$ until DNA extraction. T. absoluta adults were identified on the basis of morphological descriptions given by Genc (2016) and Visser et al. (2017).

\section{Molecular characterization of tomato leaf miner}

The incidence of T. absoluta in different states of India was confirmed by DNA barcoding technique using standardized DNA barcoding region of mitochondrial COI gene (Table 1).

\section{Table 1. Survey locations of tomato leaf miner, Tuta absoluta in India}

\begin{tabular}{|l|l|l|l|}
\hline State & Districts & Latitude- Longitude & Crop/Stage of the crop \\
\hline \multirow{2}{*}{ Maharashtra } & Nashik & $19^{\circ} 76^{\prime} \mathrm{N} 72^{\circ} 97^{\prime} \mathrm{E}$ & Tomato/Flowering and fruiting \\
\cline { 2 - 4 } & Raichur & $16^{\circ} 21^{\prime} \mathrm{N} 77^{\circ} 34^{\prime} \mathrm{E}$ & Tomato/Flowering and fruiting \\
\cline { 2 - 4 } & Kalaburagi & $17^{\circ} 32^{\prime} \mathrm{N} 76^{\circ} 83^{\prime} \mathrm{E}$ & Tomato/Fruiting \\
\cline { 2 - 4 } & Vijayapura & $16^{\circ} 83^{\prime} \mathrm{N} 75^{\circ} 71^{\prime} \mathrm{E}$ & Tomato/Flowering and fruiting \\
\hline Telangana & Mahabubnagar & $16^{\circ} 38^{\prime} \mathrm{N} 78^{\circ} 11^{\prime} \mathrm{E}$ & Tomato/Flowering and fruiting \\
\hline \multirow{2}{*}{ Tamil Nadu } & Coimbatore & $11^{\circ} 01 \mathrm{~N}, 76.95^{\prime} \mathrm{E}$ & Tomato/Flowering and fruiting \\
\cline { 2 - 4 } & Dharmapuri & $12^{\circ} 09^{\prime} \mathrm{N}, 78^{\circ} 20^{\prime} \mathrm{E}$ & Tomato/Flowering and fruiting \\
\hline Haryana & Hisar & $29^{\circ} 14^{\prime} \mathrm{N}, 75^{\circ} 72^{\prime} \mathrm{E}$ & Tomato/Seedlings, flowering \\
\hline Himachal Pradesh & Mandi & $31^{\circ} 58^{\prime} \mathrm{N}, 76^{\circ} 91^{\prime} \mathrm{E}$ & Tomato/Flowering and fruiting \\
\hline Bihar & Bhagalpur & $25^{\circ} 34^{\prime} \mathrm{N}, 86^{\circ} 98^{\prime} \mathrm{E}$ & Tomato/Flowering and fruiting \\
\hline West Bengal & Nadia & $22^{\circ} 97^{\prime} \mathrm{N}, 88^{\circ} 43^{\prime} \mathrm{E}$ & Tomato/Seedlings, flowering and fruiting \\
\hline
\end{tabular}




\section{Extraction of total genomic DNA}

Total genomic DNA of individual sample moth was extracted (5-10 individuals per location) using Cetyl Trimethyl Ammonium Bromide (CTAB) method (Augustinos et al., 2011). Each moth was individually grounded into fine powder by using TissueLyser II (QIAGEN). $300 \mu \mathrm{l}$ of pre-warmed $\left(60^{\circ} \mathrm{C}\right)$ DNA extraction buffer $(5 \%$ CTAB, $1 \mathrm{M}$ Tris $\mathrm{HCl} \mathrm{pH} 8.0,0.5 \mathrm{M}$ EDTA $\mathrm{pH} 8.0,5 \mathrm{M} \mathrm{NaCl}$ and $4 \% \beta$-mercaptoethanol) was added to the microcentrifuge tube containing T. absoluta powder. The preparation was incubated at $60^{\circ} \mathrm{C}$ for $30 \mathrm{~min}$ by gentle mixing at regular intervals. After incubation, equal volume of $300 \mu \mathrm{l}$ of chloroform: isoamyl alcohol (24:1) was added and the contents were mixed properly by inverting the tubes several times followed by centrifugation at $8000 \mathrm{rpm}$ for $10 \mathrm{~min}$ to remove the aqueous phase. Aqueous phase was transferred to new microcentrifuge tube and $150 \mu \mathrm{l}$ pre-chilled isopropanol was added and kept at $-20^{\circ} \mathrm{C}$ for $20-30$ min to precipitate the DNA. Tubes were then spun at $12,000 \mathrm{rpm}$ for $12 \mathrm{~min}$ and supernatant was discarded. The DNA pellet was washed with $70 \%$ pre-chilled ethanol, dried and dissolved in $30 \mu \mathrm{l}$ of Tris EDTA buffer (10mM Tris-HCl pH 8.0 and 1mM EDTA). The quantity and quality of DNA obtained was checked by agarose gel electrophoresis and Nanodrop 2000 (Thermo Scientific NanoDrop ${ }^{\text {TM }}$ 2000/2000c Spectrophotometer). The DNA samples were stored at $-25^{\circ} \mathrm{C}$ until further use.

\section{COI gene amplification, sequencing and phylogenetic analysis}

The total genomic DNA was extracted from 75 individual adults of $T$. absoluta collected from different locations. PCR was carried out using universal primers, forward primer (LCO1490) 5'-GGTCAACAAATCA TAAAGATATTGG-3' and reverse primer (HCO2198) 5 ' - TA A A C T T C A G GG T G A C C A A A A A AT C A - 3' (Folmer et al., 1994) to amplify a $\sim 710 \mathrm{bp}$ fragment of the mitochondrial gene $C O I$. The PCR reaction was performed in 20 $\mu \mathrm{l}$ reaction volume containing $2 \mu \mathrm{l}$ of $10 \mathrm{X}$ reaction buffer with $\mathrm{MgCl}_{2}(15 \mathrm{mM}), 0.5 \mu \mathrm{ldNTPs}(25 \mathrm{mM}), 0.5 \mu \mathrm{l}$ of each primer $(25 \mu \mathrm{M}), 0.5 \mu \mathrm{l}(5 \mathrm{U} / \mu \mathrm{l})$ of Taq DNA polymerase (BRIT, India) and $1 \mu \mathrm{l}$ of template DNA. Amplifications were performed using thermal cycler (Mastercycler gradient, Eppendorf, Germany) with an initial denaturation step of $1 \mathrm{~min}$ at $95^{\circ} \mathrm{C}$ followed by 35 cycles at $95^{\circ} \mathrm{C}$ for $45 \mathrm{sec}, 54^{\circ} \mathrm{C}$ for $45 \mathrm{sec}, 72^{\circ} \mathrm{C}$ for $1 \mathrm{~min}$ and final elongation step at $72^{\circ} \mathrm{C}$ for $10 \mathrm{~min}$. After amplification, the PCR products were resolved on $0.8 \%$ agarose gel to confirm the amplification of $C O I$ gene. The positive amplicons of $C O I$ gene from PCR product were purified by Pure Link PCR purification Kit (Invitrogen) and sequenced using Big Dye Terminator V3.1 Cycle Sequencing Kit. The selected purified PCR products were directly sequenced in both direction using LCO1490 and HCO2198 primers in ABI 3730xl cycle sequencer.
COI gene sequences of $T$. absoluta samples from different locations were confirmed through BLASTN in the GenBank database in National Centre of Biotechnology Information (NCBI) (http://www.ncbi.nlm.nih.gov/) for identification purposes. Moreover, additional sequences of COI of T. absoluta of different regions of the world were obtained from GenBank database and a multiple alignment was carried out using ClustalW in MEGA version 6 (Tamura et al., 2013). Phylogenetic relationships between T. absoluta population of different locations and other sequences of T. absoluta were analysed in MEGA version 6 (Tamura et al., 2013). Neighbor-Joining phylogeny was constructed using MEGA version 6 with bootstrap test (1000 replications).

\section{RESULTS AND DISCUSSION}

\section{Survey and incidence of tomato leaf miner}

The survey was undertaken in 11 districts belonging to 8 states of India during September 2017 to May 2018 (Table 1) for the collection of Tuta absoluta samples. The occurrence of $T$. absoluta was recorded in Maharashtra, Karnataka, Telangana, Tamil Nadu, Haryana, and Himachal Pradesh while, infestation was not observed from Eastern Indian states of Bihar and West Bengal during the survey period. Number of T. absoluta larvae trapped in pheromone traps varied depending on locations (Fig. 1). The trapped T. absoluta samples ranged from 20-100 adults per trap and suggests varied with population size and location to location. Similarly, Mutamiswa et al. (2017) observed that trapping of varying T. absoluta moths depending on location and whether the traps were installed in open tomato fields or in other habitats. Severe incidence of T. absoluta was recorded in Maharashtra (Nashik district) and Telangana (Mahabubnagar district) followed by Karnataka (Kalaburgi and Raichur districts) (Fig. 1). Recently, the occurrence of T. absoluta on tomato crop was also recorded from other

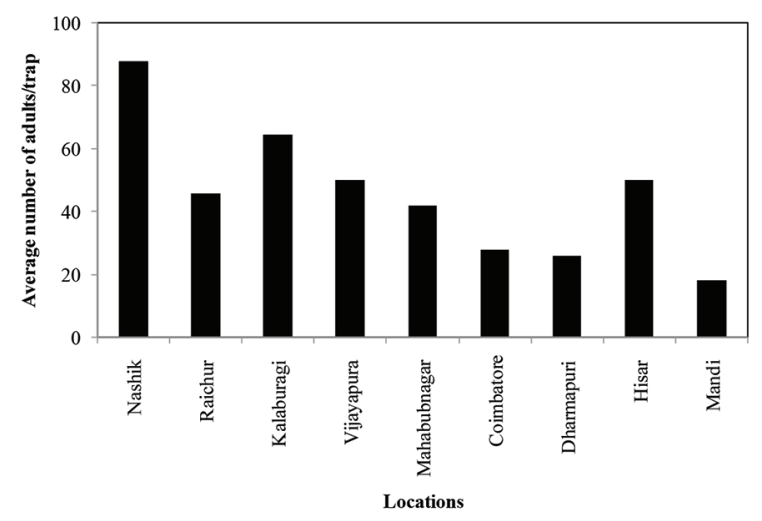

Fig. 1. Average number of Tuta absoluta male moths/trap from different locations of India by using Tuta pheromone traps. 
states of India. T. absoluta was reported first time in 201415 in and around Bengaluru (Sridhar et al., (2014) and Pune (Shashank et al., 2015). Subsequently, it has been reported from different states including Maharashtra, Tamil Nadu, Andhra Pradesh, Telangana, Gujarat, Chhattisgarh, Punjab, Madhya Pradesh (Kalleshwaraswamy et al., 2015; Kumari et al., 2015; Shashank et al., 2016; Taram et al., 2016; Ballal et al., 2016; Swathi et al., 2017; Rasheed et al., 2017; Sidhu et al., 2017; Balaji et al., 2018;). Recently, extensive survey was carried out for the occurrence of T. absoluta in Tamil Nadu and reported that severe incidence was recorded on tomato from Tamil Nadu Agricultural University (TNAU) orchard $(92.50 \%)$ followed by Krishnagiri district $(89.70 \%)$ and Dharmapuri district (82.40\%) (Balaji et al., 2018), while, certain locations of Kalyani (West Bengal), Ludhiana (Punjab), Bhubaneswar (Odisha), Raipur (Chhattisgarh), Hyderabad (Telangana), Rahuri (Maharashtra), Varanasi (Uttar Pradesh) and New Delhi (Delhi) were not infested with T. absoluta during 2014 (Sridhar et al., 2014). Later, the incidence of T. absoluta on tomato at Vegetable Research Station, Rajendranagar, Telangana State and Ludhiana and Patiala districts of Punjab was reported (Kumari et al., 2015; Sidhu et al., 2017). Therefore, the incidences of $T$. absoluta are more prevalent in Southern and Western states as compared to Northern and Eastern states of India. However, infestation of T. absoluta may also be present in other states of India which needs to be monitored.

\section{Tomato crop damage symptoms}

The tomato fields showed extensive damage due to T. absoluta. The infested leaves showed different sizes of blotches, completely devoid of chlorophyll and dried up appearance in case of severe damage. All ages of tomato fruits showed typical damage symptoms with internal feeding with pinhead exit holes and substantial frass. Early stage fruits were more infested than nearly matured fruits. Most of the matured fruits damaged by $T$. absoluta showed signs of secondary infection thus making the fruit unfit for consumption. The collected T. absoluta samples were identified based on the external characters such as moth body length (ca. 5-6 mm) and wing span (ca. 8-10 mm). Forewings narrow, with brown, grey and black mottling; hindwings lanceolate, dark grey with long cilia. Antennae, labial palpi and legs with dark brown and grey banded appearance; antennae long and filiform, labial palpi prominent and curved upward (Genc, 2016; Visser et al., 2017; Sidhu et al., 2017).

\section{Molecular analysis}

The sample populations of $T$. absoluta collected from different locations in India were characterized using standardized mitochondrial COI gene sequencing approach. DNA of the T. absoluta populations from nine locations was extracted and $C O I$ gene was amplified using $C O I$ specific primers and sequenced. The PCR amplified product length was approximately $650 \mathrm{bp}$ in all the T. absoluta samples. COI gene sequences of $T$. absoluta samples from different locations were confirmed through BLASTN in the GenBank database in NCBI. The present study samples show maximum genetic similarity with some sequences like KU565720 (Kenya), KT452897 (Oman), KY212128 (South Africa), KY619687 (India), KP814057 (India) and KJ657679 (Florida). The sequences of present study and certain reference sequences showed $100 \%$ identity in COI gene sequences. T. absoluta samples collected from different states of India also employed for $C O I$ gene amplification and further confirmed through sequencing (Sidhu et al, 2017; Balaji et al, 2018). T. absoluta samples collected from different locations of Tamil Nadu were identified by using $m t C O I$ gene sequencing and sequences were also showed maximum similarity with Oman, Bosnia and Florida (Balaji et al., 2018). So far, T. absoluta has been reported from Southern India to Northern India; now it has been stretching to Central and Eastern parts of India (Ballal et al., 2016; Sidhu et al., 2017; Rasheed et al., 2017; Balaji et al., 2018). Recently, it has been reported from adjacent countries like Bangladesh (Hossain et al., 2016) and Nepal (Bajracharya et al., 2016). This indicates that Tuta is invading new areas because of its high reproductive capacity and availability of host throughout the year and lack of strong phytosanitary measures during trade or other means of logistic.

The phylogenetic analysis revealed that two main clades were formed based on the $C O I$ gene sequences of field collected and reference Tuta samples (Fig. 2). The sequences from Turkey (MF044028), Serbia (JN417243), Montenegro (KC852870), Bosnia and Herzegovina (KC852869) were clubbed in clade II, while some sequences from Tunisia (JQ749676 and JQ749677) were grouped in clade IB. Several sequences of COI of $T$. absoluta from Florida, India, South Africa, Kenya and Oman were grouped in single calde IA (Fig. 2). These sequences showed maximum genetic similarity with present study COI sequences of $T$. absoluta. This indicates that field collected samples of $T$. absoluta populations were grouped under single clade IA revealing no genetic variation within populations and showed high genetic homogeneity, suggesting T. absoluta is being expanding to different geographical regions through spread after its introduction. Similarly, high genetic homogeneity was observed in T. absoluta samples collected from five locations of India and one from Nepal based on the mtCOI analysis (Shashank et al., 2018). Asma et al. (2017) found high genetic homogeneity using mtCOI sequences of seven Tunisian populations of T. absoluta and concluded that this 
was introduced from a single source in Tunisia. Based on

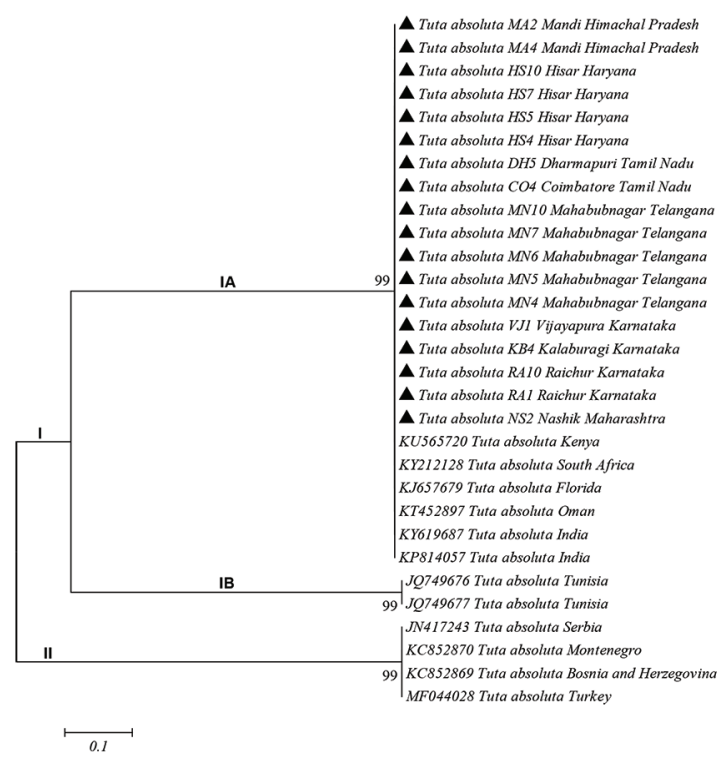

Fig. 2. Phylogenetic analysis based on representative $C O I$ gene sequences of natural population of Tuta absoluta and other sequences of $\boldsymbol{T}$. absoluta using the neighbor joining method (' $\triangle$ ', Represents current study Tuta samples).

the ITS 1, 2 and COI sequences of T. absoluta populations from the Mediterranean Basin and South America showed high genetic homogeneity (Cifuentes et al., 2011). While, eight Brazilian populations of T. absoluta using the Amplified Fragment Length Polymorphism (AFLP) technique showed differences in the populations responses to insecticides as well as host plants (Suinaga et al., 2004). Other studies on Tunisian T. absoluta using Randomly Amplified Polymorphic DNA-Polymerase Chain Reaction (RAPD-PCR) technology resulted high genetic diversity as well as in a significant differentiation between populations (Bettaïbi et al., 2012). Guillemaud et al. (2015) reported that the native population of $T$. absoluta in South America is far from genetically homogeneous based on microsatellite markers and illustrated source of invasive population with the hypothesis of single versus multiple introductions. Further research is essential to investigate the genetic variability for $T$. absoluta based on different molecular markers with larger samples from many locations and possible host-plants.

The outcome of this study including distribution and molecular characterisation of T. absoluta would be vital for future research for this insect pest. Although, this insect pest has already prevalent in different states of India, continuous monitoring of infestation on tomato and other vegetables crops is required. Currently, tomato leaf miner is being managed locally using field sanitation, sex pheromone traps, augmentation of biocontrol agents, and soft insecticides (Ballal et al., 2016). In addition, this insect pest has been considered in wide area management program including sterile insect technique for suppression/eradication in closed and/or open field conditions. However, further studies on mass rearing, radiation dose optimization and competitiveness of sterile males are needed before field validation. In addition, population dynamics, host range, insecticide resistance and natural enemies of $T$. absoluta would be another important area for future research which will facilitate effective management of T. absoluta population using IPM module.

\section{ACKNOWLEDGEMENT}

We thank Dr. V. P. Venugopalan, Associate Director (A), BioScience Group and Head, NABTD, BARC, Mumbai, for support and encouragement. We are thankful to Scientists from National Institutes and Agricultural Universities for help in collection of Tuta samples. This study was conducted under the coordinated research project (Research contract no. 22170) supported by International Atomic Energy Agency (IAEA), Vienna.

\section{REFERENCES}

Abbes K, Harbi A, Elimem M, Hafsi A, Chermiti B. 2016. Bioassay of three solanaceous weeds as alternative hosts for the invasive tomato leaf miner Tuta absoluta (Lepidoptera: Gelechiidae) and insights on their carryover potential. Afr Entomol. 24: 334-342. https:// doi.org/10.4001/003.024.0334

Asma C, Glaucia M, Wiem H, Sabrine BA, Axel H, Kaouthar LG. 2017. Some remarks on the genetic uniformity of Tuta absoluta (Meyrick) (Lepidoptera: Gelechiidae). J Entomol Zool Stud. 5: 1380-1382.

Augustinos AA, Santos-Garcia D, Dionyssopoulou E, Moreira M, Papapanagiotou A, Scarvelakis M, Doudoumis V, Ramos S, Aguiar AF, Borges PA, Khadem M. 2011. Detection and characterization of Wolbachia infections in natural populations of aphids: is the hidden diversity fully unraveled? PLoS One 16: e28695. https:// doi.org/10.1371/journal.pone.0028695

Bajracharya ASR, Mainali RP, Bhat B, Bista S, Shashank PR, Meshram NM. 2016. The first record of South American tomato leaf miner, Tuta absoluta (Meyrick 1917) (Lepidoptera: Gelechiidae) in Nepal. J Entomol Zool Stud. 4: 1359-1363.

Balaji DR, Jeyarani S, Ramaraju K, Mohankumar S, Shanmugam PS. 2018. Occurrence of South American 
tomato pinworm, Tuta absoluta (Meyrick) (Lepidoptera: Gelechiidae): An invasive pest in Tamil Nadu, India. J Entomol Zool Stud. 6: 657-662.

Ballal CR, Gupta A, Mohan M, Lalitha Y, Verghese A. 2016. The new invasive pest Tuta absoluta (Meyrick) (Lepidoptera: Gelechiidae) in India and its natural enemies along with evaluation of Trichogrammatids for its biological control. Curr Sci. 110: 2155. https://doi. org/10.18520/cs/v110/i11/2155-2159

Bawin T, Dujeu D, De Backer L, Francis F and Verheggen FJ. 2016. Ability of Tuta absoluta (Lepidoptera: Gelechiidae) to develop on alternative host plant species. Can Entomol. 148: 434-442. https://doi.org/10.4039/ tce. 2015.59

Bettaïbi A, Mezghani-Khemakhem M, Bouktila D, Makni H, Makni M. 2012. Genetic variability of the tomato leaf miner (Tuta absoluta Meyrick; Lepidoptera: Gelechiidae), in Tunisia, inferred from RAPD-PCR. Chil J Agri Res. 72: 212-216. https://doi.org/10.4067/ S0718-58392012000200008

Bettaibi A, Mezghani-Khemakhem M, Soltani Z, Makni H, Makni M. 2016. Development of polymorphic microsatellite loci for the tomato leaf miner, Tuta absoluta (Lepidoptera: Gelechiidae). J Gen. 93: 110112. https://doi.org/10.1007/s12041-013-0310-7

Biondi A, Guedes RN, Wan FH, Desneux N. 2018. Ecology, worldwide spread, and management of the invasive South American tomato pinworm, Tuta absoluta: past, present, and future. Ann Rev Entomol. 63: 239-258. https://doi. org/10.1146/annurev-ento-031616-034933

Bloem KA, Bloem S, Carpenter JE. 2005. Impact of moth suppression/eradication programmes using the sterile insect technique or inherited sterility, pp. 677-700. In: Dyck VA, Hendrichs J, Robinson A. (Eds.). Sterile Insect Technique. Springer, Dordrecht, Germany. https://doi. org/10.1007/1-4020-4051-2_26

Cagnotti CL, Andorno AV, Hernández CM, Paladino LC, Botto EN, López SN. 2016. Inherited sterility in Tuta absoluta (Lepidoptera: Gelechiidae): Pest population suppression and potential for combined use with a generalist predator. Fla Entomol. 99: 87-94. https://doi. org/10.1653/024.099.sp112

Campos MR, Silva TB, Silva WM, Silva JE, Siqueira HA. 2015. Spinosyn resistance in the tomato borer Tuta absoluta (Meyrick) (Lepidoptera: Gelechiidae). J Pest
Sci. 88: 405-412. https://doi.org/10.1007/s10340-0140618-y

Cifuentes D, Chynoweth R, Bielza P. 2011. Genetic study of Mediterranean and South American populations of tomato leaf miner Tuta absoluta (Povolny, 1994) (Lepidoptera: Gelechiidae) using ribosomal and mitochondrial markers. Pest Manag Sci. 67: 1155-1162. PMid:21495155

Desneux N, Luna MG, Guillemaud T, Urbaneja A. 2011. The invasive South American tomato pinworm, Tuta absoluta, continues to spread in Afro-Eurasia and beyond: the new threat to tomato world production. J Pest Sci. 84: 403408. https://doi.org/10.1007/s10340-011-0398-6

Desneux N, Wajnberg E, Wyckhuys KA, Burgio G, Arpaia S, Narváez-Vasquez CA, González-Cabrera J, Ruescas DC, Tabone E, Frandon J, Pizzol J. 2010. Biological invasion of European tomato crops by Tuta absoluta: ecology, geographic expansion and prospects for biological control. J Pest Sci. 83: 197-215.

Dyck VA, Hendrichs J, Robinson AS. 2006. Sterile insect technique: principles and practice in area-wide integrated pest management. Springer Science and Business Media; 2006 Feb 23.

Folmer O, Black M, Hoeh W, Lutz R, Vrijenhoek R. 1994. DNA primers for amplification of mitochondrial cytochrome coxidase subunit I from diverse metazoan invertebrates. Mol Mar Biol Biotechnol. 3: 294-299. PMid:7881515

Genc H. 2016. The tomato leaf miner, Tuta absoluta (Meyrick) (Lepidoptera: Gelechiidae): pupal key characters for sexing individuals. Turk J Zool. 40: 801-805. https://doi. org/10.3906/zoo-1510-59

Guillemaud T, Blin A, Le Goff I, Desneux N, Reyes M, Tabone E, Tsagkarakou A, Nino L, Lombaert E. 2015. The tomato borer, Tuta absoluta, invading the Mediterranean Basin, originates from a single introduction from Central Chile. Sci Rep. 5: 8371. https://doi.org/10.1038/ srep08371 PMid:25667134 PMCid:PMC4322357

Hossain MS, Mian MY and Muniappan R. 2016. First record of Tuta absoluta (lepidoptera: Gelechiidae) from Bangladesh. J Agri Urban Ent. 32: 101-105. https://doi. org/10.3954/1523-5475-32.1.101

Jalali SK, Ojha R, Venkatesan T. 2015. DNA barcoding for Identification of agriculturally important insects, pp. 13-23. In: Chakravarthy A (Eds.). New Horizons in 
Insect Science: Towards Sustainable Pest Management. Springer, New Delhi, India. https://doi.org/10.1007/97881-322-2089-3_2

Jham G. N., Friguetto R. T., Attygalle A. B., Vilela E. F., Svatos A., Meinwald J., Uchoa-Fernandes M. A., Ferrara F. A. 2001. Pp 206. In: Vilela EF and Della Lucia TMC. (Eds.), Identificação, sintese e avaliação do feromonio sexual de Tuta absoluta (Meyrick) (Lepidoptera: Gelechiidae).

Kalleshwaraswamy CM, Murthy MS, Viraktamath CA, Kumar NK. 2015. Occurrence of Tuta absoluta (lepidoptera: Gelechiidae) in the Malnad and Hyderabad-Karnataka regions of Karnataka, India. Fla Entomol. 98: 970-971. https://doi.org/10.1653/024.098.0326

Karthika P, Krishnaveni N, Vadivalagan C, Murugan K, Nicoletti M, Benelli G. 2016. DNA barcoding and evolutionary lineage of 15 insect pests of horticultural crops in South India. Karbala Int J Mod Sci. 2: 156-168. https://doi.org/10.1016/j.kijoms.2016.03.006

Kumari DA, Anitha G, Anitha V, Lakshmi BK, Vennila S, Rao NH. 2015. New record of leaf miner, Tuta absoluta (Meyrick) in Tomato. Insect Environ. 20: 136-138.

Kuyulu A, Genç H. 2016. Effects of gamma radiation on tomato leaf miner, Tuta absoluta (Meyrick) (Lepidoptera: Gelechiidae). World Academy of Science, Engineering and Technology. Int J Biol Biomolecular Agri Food Biotechnol Eng. 10: 451-455.

Lietti MM, Botto E, Alzogaray RA. 2005. Insecticide resistance in argentine populations of Tuta absoluta (Meyrick) (Lepidoptera: Gelechiidae). Neotrop Entomol. 34: 113-119. https://doi.org/10.1590/S1519$566 \times 2005000100016$

Mutamiswa R, Machekano H, Nyamukondiwa C. 2017. First report of tomato leaf miner, Tuta absoluta (Meyrick) (Lepidoptera: Gelechiidae), in Botswana. Agri Food Security 6: 49. https://doi.org/10.1186/s40066-0170128-2

Rasheed VA, Rao SK, Babu TR, Krishna TM, Srinivasulu A, Ramanaiah PV. 2017. New record of invasive South American Tomato Leaf Miner, Tuta absoluta (Meyrick) (Lepidoptera: Gelechiidae) on Tomato in Andhra Pradesh. Int J Pure App Biosci. 5: 654-656. https://doi. org/10.18782/2320-7051.2940

Shashank PR, Chandrashekar K, Meshram NM, Sreedevi K. 2015. Occurrence of Tuta absoluta (Lepidoptera:
Gelechiidae) an invasive pest from India. Indian $J$ Ent. 77: 323-329. https://doi.org/10.5958/09748172.2015.00070.X

Shashank PR, Suroshe SS, Singh PK, Chandrashekar K, Nebapure SM, Meshram NM. 2016. Report of invasive tomato leaf miner, Tuta absoluta (Lepidoptera: Gelechiidae) from northern India. Indian J Agri Sci. 86: 1635-1636.

Shashank PR, Twinkle S, Chandrashekar K, Meshram NM, Suroshe SS, Bajracharya AS. 2018. Genetic homogeneity in South American tomato pinworm, Tuta absoluta: a new invasive pest to oriental region. 3 Biotech 8: 350. https://doi.org/10.1007/s13205-018-1374-0

Sidhu SK, Sridhar V, Sharma A, Asokan R. 2017. Report on the occurrence of South American Tomato moth, Tuta absoluta (Meyrick) in Punjab, India as evident from trap catches and molecular diagnosis. Pest Manage Hort Ecosys. 23: 89-91.

Siqueira HÁ, Guedes RN, Picanço MC. 2000. Insecticide resistance in populations of Tuta absoluta (Lepidoptera: Gelechiidae). Agri For Entomol. 2: 147-153. https://doi. org/10.1046/j.1461-9563.2000.00062.x

Siqueira HA, Guedes RN, Fragoso DD, Magalhaes LC. 2001. Abamectin resistance and synergism in Brazilian populations of Tuta absoluta (Meyrick) (Lepidoptera: Gelechiidae). Int J Pest Manage. 47: 247-251. https:// doi.org/10.1080/09670870110044634

Sridhar V, Chakravarthy AK, Asokan R. 2014. New record of the invasive South American tomato leaf miner, Tuta absoluta (Meyrick) (Lepidoptera: Gelechiidae) in India. Pest Manage Hort Ecosys. 20: 148-154.

Suinaga FA, Casali VW, Picanço M, Foster J. 2004. Genetic divergence among tomato leaf miner populations based on AFLP analysis. Pesq Agropec Bras. 39: 645-651. https://doi.org/10.1590/S0100-204X2004000700005

Swathi P, Swathi B, Das SB, Sridhar V, Giribabu O, Snehalatha G, Raypuriya N. 2017. First report of South American tomato leaf miner, Tuta absoluta (Meyrick) from Madhya Pradesh, India. Pest Manage Hort Ecosys. 23: 92-93.

Tamura K, Stecher G, Peterson D, Filipski A, Kumar S. 2013. MEGA 6: molecular evolutionary genetics analysis version 6.0. Mol Biol Evol. 30: 2725-2729. https:// doi.org/10.1093/molbev/mst197

PMid:24132122 
Tan KH. 2000. Area-wide control of fruit flies and other insect pests. Joint proceedings of the international conference on area-wide control of insect pests and the fifth international symposium on fruit flies of economic importance. Ann Entomol Soc Am. 94: 960-961.

Taram SK, Ganguli JL, Ganguli RN, Singh J. 2016. South American tomato borer, Tuta absoluta (Povolny): A new threat on tomato in Raipur, Chhattisgarh. J Appl Zool Res. 27: 53-56.

Tonnang HE, Mohamed SF, Khamis F, Ekesi S. 2015. Identification and risk assessment for worldwide invasion and spread of Tuta absoluta with a focus on Sub-Saharan Africa: implications for phytosanitary measures and management. PLoS One 10: e0135283. https://doi.org/10.1371/journal.pone.0135283
Visser D, Uys VM, Nieuwenhuis RJ, Pieterse W. 2017. First records of the tomato leaf miner Tuta absoluta (Meyrick, 1917) (Lepidoptera: Gelechiidae) in South Africa. BioInvasions Records 6: 301-305. https://doi. org/10.3391/bir.2017.6.4.01

Zappala L, Biondi A, Alma A, Al-Jboory IJ, Arno J, Bayram A, Chailleux A, El-Arnaouty A, Gerling D, Guenaoui Y, Shaltiel-Harpaz L. 2013. Natural enemies of the South American moth, Tuta absoluta, in Europe, North Africa and Middle East, and their potential use in pest control strategies. J Pest Sci. 86: 635-647. https://doi. org/10.1007/s10340-013-0531-9 